\title{
"Our Little Secret": A History of Writing Centers, Pre- To Post-Open Admissions
}

\author{
Elizabeth Boquet \\ Fairfield University, eboquet@fairfield.edu
}

Follow this and additional works at: https://digitalcommons.fairfield.edu/english-facultypubs (C) 1999 by National Council of Teachers of English

\section{Peer Reviewed}

\section{Repository Citation}

Boquet, Elizabeth, "''Our Little Secret": A History of Writing Centers, Pre- To Post-Open Admissions" (1999). English Faculty Publications. 2.

https://digitalcommons.fairfield.edu/english-facultypubs/2

\section{Published Citation}

Boquet, Elizabeth. "'Our Little Secret': A History of Writing Centers, Pre- To Post-Open Admissions." College Composition and Communication 50.3 (Feb 1999): 463-482.

This item has been accepted for inclusion in DigitalCommons@Fairfield by an authorized administrator of DigitalCommons@Fairfield. It is brought to you by DigitalCommons@Fairfield with permission from the rightsholder(s) and is protected by copyright and/or related rights. You are free to use this item in any way that is permitted by the copyright and related rights legislation that applies to your use. For other uses, you need to obtain permission from the rights-holder(s) directly, unless additional rights are indicated by a Creative Commons license in the record and/or on the work itself. For more information, please contact digitalcommons@fairfield.edu. 


\section{Elizabeth H. Boquet \\ "Our Little Secret": A History of Writing Centers, Pre- to Post-Open Admissions}

Judy Russell didn't have an appointment but she waited anyway outside the new writing center at Fairfield University...She had never been to the writing center before and had no idea what it would be like.

"My history teacher recommended the center to me," she said. "I hope I can get a fresh idea. I just didn't want to do a paper on Louis XIV."

"It was terrific," Judy said. "She came up with it in two minutes. It was like her own little secret that she was saving for someone." (Lomuscio A6)

7 en minutes later, the article goes on to tell us, Judy beamed with enthusiasm as she walked down the hall. A consultant

from the center, English professor Laura Ress, had just given her a unique topic: how the French went to Ireland to help with the Irish Revolution. The photo inset shows a student seated next to Professor Ress, who is apparently talking and, pen in hand, seems poised to write.

I came across this article as I searched the archives of the writing center I now direct, the writing center at Fairfield University. Judging solely from this introduction, James Lomuscio's article, "Students get help at writing center," published in the Fairfield Fairpress on March 3, 1982, confirms the

Elizabeth Boquet directs the writing center and is an assistant professor of English at Fairfield University. Her active participation on both national and regional writing center boards has led to her interest in researching the development of writing center theory and practice. Her current research interests involve the examination of theoretical models for staff training and conceptual representations of writing center work. 
suspicions of many faculty and administrators and the worst fears of writing center professionals. At first glance, the student seems the passive recipient of the tutor's expertise and knowledge. Judy walks away with the tutor's secret, a slant on the topic that Judy acknowledges the tutor "came up with."

The rest of the article, however, consists of interviews with area writing center directors (from Fairfield, Yale, and the University of Connecticut), all of whom express fairly contemporary views on the methods and missions of their writing centers. The directors, for example, attribute the growth of writing centers to a recognition that incoming students have had little experience writing for "diverse audiences and in different subject areas" (A6). For this reason, these directors stress that their writing centers are open to anyone, and they cite examples of students coming to the center to work on graduate school applications and senior theses, as well as first-year composition papers. Dr. Mariann Regan, who developed the writing center at Fairfield University, explains, "The consultant works by questioning the student." Students cannot simply drop off their papers, Regan quips, because "we're not a laundry" (A6). Instead, she emphasizes the importance of students working with consultants.

It is difficult to know which of these is the master narrative in this case. Is it the one in which Judy leaves the writing center after ten minutes (!) to write a paper on the topic Professor Ress has "given" her? (Is Judy even capable of writing such a paper?) Or is it the one in which students are questioned, drawn out, in which student input is valued and encouraged? Is the writing center, in other words, primarily a space, a "laundry" where work is dropped off and picked up, where students are brushed off and cleaned up? Or is it primarily a temporality, an interaction between people over time, in which the nature of the interaction is determined not by site but by method?

When I began this history, I would have been afraid to admit how often the writing centers I've worked in-and now how often the one I directresembles the 1982 Fairfield writing center of Mariann Regan and Laura Ress. Too often, I've felt that my life in the writing center is a secret one, as I struggle with the injunction not to reveal too much in a writing center session, as I search for a positive spin on one of the writing center's lessthan-successful ventures. My tutors now lead secret lives of their own, sneaking into my office and closing the door behind them so that they might broach a sensitive issue in private. Sometimes such privacy is warranted: when their concerns hint at their discomfort with a professor's pedagogical approach, for instance. Other times, though, their secrecy suggests an insecurity with their own perceived lack of expertise, and I wonder why they feel the question is worthy of such behavior. In fact, what they have to say is almost always less troubling than how they say it: the 
submissive posture, the eyes cast downward, the barely audible latching of the door, the thinly-veiled frustration in the voice.

As a graduate student, I turned to the literature on writing centers, I believe, searching for some consistency, so that I might be honest, in some idyllic sense, about what happens here. What I've learned since I began this history five years ago-and they are five years that have seen me move beyond my graduate program and into a permanent position-is to think differently about this secrecy, to view it not as hypocritical or dishonest or even (to be generous) strategic, but instead as endemic to the institutional position of writing centers.

I offer this piece of history of my own center, the writing center at Fairfield University, because it is so typical of the discourse framing writing center theory and practice, a discourse so perfectly at odds with itself. I say perfectly at odds because the at-odds-ness of the discourse so successfully escapes notice, suggesting that the contradiction exists, in the minds of those who use it, in the equilibrium that is characteristic of all apparently natural things. My aim here is in part to expose the existence of this contradiction in order to make possible a more self-conscious appraisal of the identity of writing centers at an especially crucial time in their history. This brief history of writing labs/clinics/centers makes evident the tension between the writing center whose identity rests on method and the writing center whose identity rests on site by offering an analysis of the sequence of discursive maneuvers that collapsed and distinguished and collapsed again the difference between method and site. This prying apart of space and method represents a rare but necessary move in our discussions of pedagogical practices.

In general our field has failed to consider writing centers an appropriate area of inquiry into composition's politics of location, yet writing centers remain one of the most powerful mechanisms whereby institutions can mark the bodies of students as foreign, alien to themselves. Foucault shows us, in the first pages of Discipline and Punish, that to extend power is to put it at risk. This has certainly been true of the university's relationship to the writing center, a symbiosis highlighting the degree to which institutional power becomes most vulnerable at the very point at which it becomes most visible. Nowhere in our field has this tension been more apparent than in the writing center, a space where the consolidation of power shifts as the idea of the writing center metamorphoses from being one whose identity rests on method to one whose identity rests on site, and back again.

\section{The Emergence of the Writing Laboratory Method}

Much ink has already been spilled, in this and other forums, on the 19th century "creation" of composition. It is difficult to know, from there, 
where to begin to trace the germ of an idea for the writing lab (as it was first called). Is it, as Neal Lerner has suggested in "The Writing Conference as Dominant Practice," in the proliferation of the conference method of the late 1800s? Is it, as Anne Ruggles Gere's work might suggest, in the "extracurriculum" of composition? Before answering this question, I want to look at what is at stake in the potential conclusions we draw. If we accept that contemporary writing centers grew out of early methods, then we have strong support for a reading of writing centers as producing and sustaining hegemonic institutional discourses. Such a reading leads us to theories like that of Grimm's regulatory model, which constructs the writing center as an institutional site concerned with controlling the production of literacy. If, on the other hand, we locate writing center origins in the extracurriculum, we then set the precedent for a counter-hegemonic model of writing center operations, one which attempts to wrest authority out of the hands of the institution and place it in the hands of the students. (See, for example, the work of Marilyn Cooper and John Trimbur.)

Personally, I find Gere's account more appealing, though it is difficult to place the writing lab in Gere's extracurriculum of composition, precisely because the sites described by Gere were designed to foster empowerment and autonomy, ideas for which there is painfully scant support in the early articles on the writing lab method. I find locating the writing lab in Gere's extracurriculum of composition tempting because this configuration highlights the politics of location that have proven so crucial in discussions about the institutional placement of writing centers. As much as I might like to think that the extracurriculum exerted the primary influence over the development of writing labs, ultimately I am inclined to trace the development through the more typical institutional channels. Doing so makes Lerner's conference method theory more probable, particularly when we consider the intimate links between early writing labs and firstyear composition instruction. Neither account, however, makes sense of the at-odds-ness noted throughout. The origin of that story of the writing center, the story that writing center staff live on a day-to-day basis, is in the later moment when the lab shifted from method to site and when the liberatory possibilities of the writing center arose, in Foucauldian terms, as an "accident," an ever-present, always possible, though not necessarily intended, outcome ("Nietzsche" 144).

The writing laboratory of the early 20th century was conceived of not as a place at all but rather as a method of instruction, the key characteristic of which appears to have been that all work was to be done during class time, enabling the instructor "to eliminate errors or other weaknesses at their source and not allow their use at all, thus precluding the possibility of their becoming habitual through thoughtless repetition" (Horner 218). ${ }^{1}$ Under the careful gaze of the instructor, students labored, afforded the opportuni- 
ty first to self-correct errors in drafts and, failing that, to have their papers corrected immediately, line by line, by the instructor himself, thereby encouraging the internalization of discursive norms.

That the laboratory method changed the conditions under which students composed seems true enough. Students went from listening to instructors talk about writing to actually doing the writing themselves. That the method emerged from or resulted in a fundamental reconception of knowledge production and dissemination in the classroom or beyond, however, seems doubtful. Rather, it seems to have simply shifted, slightly but significantly, the site of discursive regulation.

\section{Autonomous Writing Labs}

A slow drift occurred between the 1920s, when the writing lab was most recognizably a method of instruction, and the 1940s, when it became most recognizably a site, and the writing on writing labs begins to show evidence of the tension emerging between the institutional space of the writing center and the individual pedagogies enacted in that space.

Structurally, writing labs remained closely tied to the scene of the classroom and became integral parts of the institutional desire to track students according to ability. At some institutions, students each week attended a writing lecture and a writing lab. ${ }^{2}$ Pedagogically, though, instructors began to demonstrate an awareness of the benefits of the writing labs for students, independent of the administrative hierarchies in which they functioned (Stanley; Grandy). These authors framed the work of the writing lab as encouraging dialogue, even dialectic, much as we in writing centers do today. ${ }^{3}$ The execution of that work proceeded, however, in a manner that belied consideration of writing lab space in those terms. Instead, individual students-like Judy, whom we met at the beginning of this piecewere portrayed as having been shown the light, for which they were eternally grateful. For example, when Stanley, the first director of the writing lab at the University of Iowa, writes of the benefits of having a student think through what he or she wants to say before writing it, she claims, "In this way is the once baffled one now truly learning to guide his own thinking" (425).

All in all Stanley sees the writing center as "com[ing] very close to meeting the ends of true education" by encouraging students to be independent writers and thinkers (428). She does not, however, elaborate on what such an ideological becoming might entail, and her readers are left to wonder if true education means internalizing organizational patterns and mechanical rules, as the early part of her article suggests, or if it has more to do with the empowerment she writes of at the end of her article, "the tangible evidence of accomplishment, eagerness and 
industry and pride [which] begin to replace indifference and laziness; [the] fear and antagonism [which] begin to give way to self-confidence and optimism" (428).

Stanley's article, one of the first to tease out the pedagogical significance of the writing lab, is also perhaps the first to hint at the at-odds-ness of the writing lab's existence. Her rhetoric suggests the degree to which the site of the writing lab carries with it the politics of the writing lab, a fact which becomes clear to her readers when they learn years later that, as the writing lab at Stanley's University of Iowa becomes increasingly autonomous, it also becomes increasingly tied to specific students, namely remedial students, and tied to serving a specific curriculum. Stanley's earlier vision of the writing lab as a site for dialectical engagement-though problematic in its execution, as noted earlier-is supplanted by a view of the writing lab as a center for remediation, replaced by what is later termed the lab's "official function: to provide instruction for the students whose placement themes did not meet departmental standards" (Kelly 5).

The call for standards and individuation, like that taking place at the University of Iowa, was part of a larger political agenda driving educational initiatives at this time, as Berlin has discussed at great length elsewhere (see Rhetoric and Reality). Two resultant educational initiatives (both an outgrowth of World War II) spurred on the transition from classroombound to free-standing labs: (1) the appointment of a Presidential Commission on Higher Education, charged with studying the role of higher education in shaping and maintaining the democratic fabric of the nation and (2) the communications programs appearing on campuses nationwide. ${ }^{4}$ Taken together, these initiatives resulted in a curriculum geared to present information in conservative, current-traditional terms, ostensibly, according to Berlin, "in the service of the democratic ideals recently challenged from abroad," ("Writing Instruction" 202) an emphasis resulting in a focus on the individual, practical, skills-centered nature of composing (Berlin, Rhetoric and Reality 97). The writing labs they spawned focused primarily on the individual rather than the social nature of composing, and individual improvement was often seen as necessary only for remedial students. Hence the situation at University of Iowa.

Another striking example occurred at the University of North Carolina's Composition Condition Laboratory, a center designed specifically as a grammar fix-it shop. At UNC, if an instructor thought that a student needed to work on his (or possibly her) writing, the instructor would place a " $\mathrm{CC}^{\text {" }}$ behind the final grade, indicating that the student had, apparently, a "composition condition" and should be tested at the writing lab. Descriptions such as these place increasing responsibility on the student for his or her failure and decreasing responsibility on the educational system, specifically 
on classroom instructors. The bodies of writers are thus publicly marked for their deficiencies and treated appropriately.

What is lacking in the UNC example is any discussion or characterization of the work done in the "CC" lab. Readers are left to wonder, in other words, about the relationship between site and method in this instance. After all, a "CC" may tell us something about the institutional climate in which the lab was operating, particularly since the UNC composition laboratory apparently served as a deterrent on campus, but it tells us nothing beyond that. ${ }^{5}$ I continue to remind myself to work against the temptation of focusing on the shortcomings of much of the early literature, and my own writing center helps to keep me honest in this regard. This morning, for example, a student arrived in my writing center with a previously graded paper which he was trying to revise. Set apart from the instructor's comments, stretching diagonally across the bottom of the page, was one dictate: "Go to the Writing Center!" This directive strikes me as not so different from the "CC" of decades ago, and it is a frequent occurrence in the writing center, one about which I have been able to do very little. Certainly I can talk to my colleague about this problematic demand, explain to him how it makes our job in the writing center that much more difficult. But I probably cannot significantly impact the perspective which led him to pen this, even if on occasion I do succeed in getting him to stop writing it.

Though my colleague still sees the writing center as a disciplinary measure, I would like to think that what students find once they arrive here is something exceeding that. While I resist the formulation of the writing center as a "safe house," as an unthreatening environment where students feel free to explore ideas, I do believe that it offers possibilities not intended or accounted for in the original administrative idea of the writing center. Such accidents exploit the tension set out in this essay. And, as we move through the history, we can begin to see more clearly the emergence of these counter-institutional impulses.

The most significant of these moves occurred when the autonomous writing lab gained legitimacy through its association with psychological principles. The field of composition has long relied on its association with psychology to shore up its claims about language development and acquisition. Beginning in the 1940s, psychology offered educators another means of thinking about the ways of regulating behavior, a model based less on the behaviorist principles alluded to above-with its fear of reinforcement and emphasis on aversion-and more on the cognitivist principles gaining respect in psychotherapeutic circles. Davidson and Sorenson, the two most vocal proponents of this psychotherapeutic approach to writing lab work, advocate an approach they refer to as Rogerian nondirective counseling, a method which has psychotherapists ask questions in 
order to draw out their patients, leading to knowledge these clients presumably already possess. Rogerian nondirective counseling provided then yet another means for individual students to be held accountable for their own successes as well as for their shortcomings by making students responsible for accessing information which continually eludes them.

More importantly, however, the Rogerian nondirective method succeeds in securing the space of the writing lab as sacrosanct, as distinct from the classroom, a space where students should feel secure in their expression of thoughts and ideas, as they should in a therapist's office. It is through this therapeutic closed-door policy that writing centers begin to engage in some version of counter-hegemonic work, supported by a doctor-patient privilege which ushers in both a model for professionalism and an invitation for tutors to assume a neutral posture (at least as an ideal).

It is also at this time that we begin to see the institutional goals for these labs and clinics, goals clearly linked to remediation, to preparing the un(der)prepared, conflicting with the goals of individual writing center staff members, who reject the marginalization of either the writing lab or the students who chose (or were sent) to use it. Writing labs begin to be characterized in the literature as places where average students can get help with content and organizational problems, a step forward from the primarily remediation-oriented labs mentioned earlier. They become places where the time lag between writing and response can be addressed and where the importance of immediate feedback on writing is valued and encouraged (Millet and Morton). Students are encouraged to write about what interests them, and models for response are cast in more collaborative, even dialogic, terms (Perrin). It remains unclear whether institutions viewed their writing centers in this manner. In fact, it seems more likely that the literature at this time offers the beginnings of an articulation of professionalism predicated on doctor-patient privilege bordering at times on the collusion of staff and students against administration, a familiar refrain in later writing center work.

Davidson and Sorenson themselves, in their advocacy of the psychotherapeutic approach to tutoring, invoke narratives recognizable to contemporary composition professionals-the problem of writer's block, the teaching of grammar only in context, and the goal of producing independent writers, for example (86). In their writing about the communications course, however, Davidson and Sorenson fall prey to the same kinds of stock characterizations as Stanley, with the clinician poised, deus ex machi$n a$, to rescue the plot. They write, for example, that the writing clinic benefits all students, but not for the reasons we might expect. They note that exceptional students are often not "adequately adjusted in the field of human relations" and that "students who have received A grades in high school English are often egocentric introverts" (84). 
Because the clinic's strategies blurred the line between composition and therapy in ways that left many professionals uncomfortable and pathologized student behavior (as the above quote suggests), Denver's methods quickly came under fire. Shortly after Frederick Sorenson left the University of Denver, he publicly recanted his earlier methods in College English:

The "Writing Clinic" was a tragic semantic blunder on the part of somebody who figured that if there was a Speech Clinic and a Reading Clinic, there should be a Writing Clinic too. (325)

Of course, he fails to explain why the Speech Clinic and the Reading Clinic were not "tragic semantic blunders" as well.

\section{The "Mysterious Disappearance" of the Writing Lab}

Sorenson's recantation began to seem premonitory as I searched for traces of writing labs and clinics in the literature of the mid- to late 1950s; for, while writing labs seemed to hold great promise in the early part of that decade (see Moore 1950), they effectively disappear shortly thereafter. The disappearance may in part simply be attributed to "a limitation in the documentary record" (Stephen North, personal correspondence, 7 January 1998). The question remains, though: Why, just as writing labs were gaining some legitimacy as an area of academic inquiry, did they suddenly fall out of intellectual favor?

In his 1995 article "Early Writing Centers: Toward a History", Carino considers this disappearance curious, noting, "One would think that the postSputnik emphasis on American education would have spawned more [writing labs] in the late 1950s and early 1960s" (108). Here, Carino is partially correct: the Cold War did indeed generate public interest in the adequacy of American students' educational preparedness. That interest manifested itself, however, primarily in the arenas of math and science. ${ }^{6}$

A more plausible theory, also briefly entertained by Carino, involves the resurgence of linguistics (108). Coupled with the cross-disciplinary rise of formalism in the 1950s, linguistics provided a mechanism through which readers could go in search of a stable, independent meaning in each text. The task of writers, then, was simply to produce such a text. (See "Where Did Composition Studies Come From: An Intellectual History," Nystrand, Greene, and Wiemelt). The rise of linguistics, particularly structural linguistics, in the composition classroom of the 1950s marked a return to the scientific, objectivist thought of earlier eras. It rationalized the study of language, taxonomized the complexities of human discourse. The implications for writing labs become clear when Guyer promises that, through linguistics, these forms and patterns "become manipulable not only 
intuitively by gifted students but consciously by all students" (310). So, instead of leading us to the lab, as the scientific (lecture-lab) model did in the first few decades of this century, this empirical model lent itself to whole class techniques, patterns which once mastered, en masse, enabled any one student theoretically to compose a competent five-paragraph theme. The interdependence of site and method in writing labs had not been so clear since the writing lab method emerged in early twentieth century classrooms. If students did not need to be segregated-if a method were developed, in other words, which offered equal promise to both the strongest and the weakest student-then there would be no need for a separate site, no cause for treatments or cures.

Of course, some writers were in fact left behind in the large-group explanations of phonemes and morphemes and syntax and lexicons-the non-elect, as Harvard called them in the 1870s; the non-trads, as they are often called today-but they were being funneled off university and fouryear college campuses in droves in the late 50s and early 60s, shunted off instead to what Shor calls the "budget campuses," community colleges (Culture Wars 3). ${ }^{7}$ This mass segregation of working class students onto two-year campuses lessened the need for institutional defense mechanisms like writing labs, at least for a while, enabling four-year colleges and universities to get back to the "real business" of teaching. Kitzhaber, for instance, notes "an accelerating decline in the number of remedial courses being offered on college campuses" (qtd. in Berlin, Rhetoric and Reality 128). He also notices that "proficiency exams in English for sophomores and juniors were being eliminated because so few students were failing them" (128). A final key observation is the one in which Kitzhaber acknowledges, "As provisions for less able students were decreasing, those for the best students were increasing" (128).

\section{Writing Centers, Open Admissions, and the Literacy Crisis}

Despite the field's insistence that writing centers are institutionally specific (which they are-as is every program on a college campus, to one degree or another), the histories of open-admissions writing centers share some striking similarities. From the beginning, these writing centers were forced to take a defensive stance within their institutions. The theme of crisis intervention is repeated over and over again in the scant histories written about writing centers during the 1970s, as writing centers were created largely to fix problems that university officials had difficulty even naming, things like increasing enrollment, larger minority populations, and declining (according to the public) literacy skills. Exactly how writing centers were to address these problems, however, is never quite clear. ${ }^{8}$ Writing 
centers begin to re-appear in the literature at this time, albeit infrequently. Site and method come into more direct conflict as this period progresses, largely because authors move away from mere descriptions of their labs (a tactic which kept the literature fairly focused on site) and toward theoretical justifications of writing lab work. Situating labs within a philosophical framework leads quite naturally to discussions of method, and these conversations make apparent the methodological differences operating in the various lab arrangements. The discussions fall into fairly consistent "camps": (1) those who champion auto-tutorial methods and materials, (2) those who critique these types of programmed instruction, and (3) those who seek alternatives to the traditional forms of instruction heretofore provided by writing labs.

For all its faults, the auto-tutorial model had significant implications for the marriage of site and method in the writing lab. Descriptions of auto-tutorial labs, like those provided in York College's COMP-LAB materials, make obvious as never before the space of the writing lab as a technology. The salient features of these spaces were their headsets, audiotapes, and workbooks, all of which allowed the students to work individually (without a tutor, that is) on grammatical errors (Kirkpatrick 17). Cost was often a key factor in implementing the autotutorial model, since one-time equipment costs are easier to justify administratively than ongoing costs such as staffing. These writing labs were also not without their own pedagogical philosophies, rationales which usually appeal to the participatory nature of the autotutorial, the individual pacing, and the increased sense of student responsibility. One wonders, however, whether students want or even deserve to shoulder that burden. As Lerner ("Drill Pads") notes, these modules conveniently place the blame for students' difficulties on them, rather than acknowledging the responsibilities of their teachers or the educational system or society at large (np).

In a variety of forums, critics of programmed instruction advocate a more careful consideration of work appropriate to student needs and respectful of student intelligence (Almasy; Veit). In his defense of individualized instruction, Veit claims, "Machines take a narrow view of students' needs" (2). While acknowledging the appeal of programmed instruction in notoriously under-staffed, under-funded labs, these critics nevertheless feel committed to what they deem the fundamental principle of the writing lab: one-to-one contact with "a human being who cares" (2). This philosophy, an extension of the Rogerian non-directive/mirroring model of writing lab operations, led these labs to define themselves in opposition to their auto-tutorial counterparts, to characterize the lab spaces as nonthreatening (however specious) and to fill them with creature comfortscouches, plants, coffee pots, posters. 
Other labs began to fill their spaces for the first time with peer tutors, a move leading to perhaps the greatest long-term implications for the sitemethod dichotomy in writing labs. Describing his experiences with tutorial assistance in the late 60 s and early 70s, Bruffee observed that those students having difficulty with their classes refused to take advantage of the programs designed to assist them

because [these programs] seemed to them merely an extension of the work, the expectations, and above all the social structure of traditional classroom learning. And it was traditional classroom learning that seemed to have left these students unprepared in the first place. What they needed... was help of a sort that was not an extension but an alternative to the traditional classroom. ("Peer Tutoring" 4)

The solution, according to Bruffee, is peer tutoring, an approach which changes not "what people [learn] but, rather, the social context in which they [learn] it" ("Peer Tutoring" 5).

The presence of peer tutors addressed, though imperfectly, both the call for human contact and the very real fiscal constraints faced by labs (since peer tutors are less expensive to employ than faculty). Peer tutors also deepened the writing lab's debt to psychology by relying once again on major figures in that field (specifically, Piaget and Vygotsky) to provide a philosophical rationale for current writing lab operations.

For the first time, the space of the writing center is characterized as active and tutors are portrayed as having as much to learn as they have to teach. Bruffee offers his rationale for the peer tutorial by citing several studies on the importance, and the under-utilization, of peer-group influence on intellectual development. Though he expects that students would "learn and practice judgment collaboratively" ("Brooklyn Plan" 450), he notes what he calls "two not entirely expected results" of this plan: the first, that students need more than help with so-called "skills" development; and second, that the peer tutors themselves actually seem to be benefiting from the program. He writes, "There is nothing in the literature on peer tutoring which would lead us to expect that average and somewhat above-average undergraduates acting as tutors could develop so rapidly through a process of peer influence a capacity so essential to mature thought" ("Brooklyn Plan" 451). By the middle of the article, Bruffee is on to the transformative potential of the writing center: "Peer-groups can influence the means, power, and criteria by which we make discriminations" ("Brooklyn Plan" 453). So, while the original intention of the Brooklyn plan was merely a modified version of the older lab model, with weaker students coming to benefit from the knowledge of stronger students, the plan actually came to embody what would become the focus of Bruffee's work in the field-the 
benefits of collaborative learning for all participants-while foreshadowing the radical educational thrust of later writing center theorists (Warnock and Warnock, Cooper, Trimbur, Kail and Trimbur).

The presence of peer tutors affected, naturally, the space of the writing lab and the method of writing lab operations, both in terms of the manner of work with students and the preparation of the staff for such work. Upon entering the writing labs, students for the first time saw faces that resembled their own and they saw signs of student investment in that space. Students ceased to simply visit the writing center; they began, with the advent of peer tutoring, to inhabit it, to hang hand-lettered renditions of favorite quotations on the wall, to jot down jokes on the board, to leave their own work on the tables while answering a question. Peer tutors also inhabit student writing in a manner that their faculty counterparts cannot, simply because of their different relationship to the academic system of rewards.

At the same time, peer tutors necessitated the gradual development of a method for training writing lab staff. (Implicit in the rise of this issue is, of course, the assumption that faculty would know how to tutor but students would not.) This training began as, and remains, a hybrid, like the writing center itself, a mix of institutional accountability and critique, of creditbearing courses and informal discussions over pizza or doughnuts. The tenor of national discussions about the work taking place in these labs changed as well. Beginning in the late 1970s, articles on writing labs in CCC and College English focus almost exclusively on staff selection and training. Much of the work at this time highlights, as Bruffee's Liberal Education article did, the non-authoritarian orientation of the peer tutor's writing lab, contrasting it, in a move that continues to dog writing center staff, with the inherently hierarchical classroom configuration. (See, for example, the February 1980 issue of CCC.) In offering specific advice and suggestions for setting up a peer tutoring program, these authors feel compelled, for obvious reasons, to provide a convincing rationale for embarking upon such an undertaking in the first place.

\section{Writing Centers and Post-Open Admissions}

A post-open admissions category is, of course, a slippery slope: How does one know when or whether open admissions became "post?" The concerns of open admissions writing labs were not new, having been factors in the writing lab's existence throughout its history. And the problems of open admissions writing labs have yet to be solved. With that said, I am placing the beginning of the post-open admissions writing center somewhere around 1980, give or take a year or two. ${ }^{9}$ By this time, national forums for writing centers have emerged, and influential figures-like Bruffee, Harris, and 
North-have appeared on the national scene, publicly hashing out, not merely reporting, issues of interest to a growing writing center community. Truth be told, with a few notable exceptions, the most interesting work in writing centers, post-1980, is to be found not in the pages of the major journals in composition or English studies but in the forums designed specifically to house writing center work. The relationship between writing centers and composition studies, as that relationship has been represented in the pages of CCC and College English, becomes increasingly ambivalent, with writing center scholars continually called on to articulate (as per Grimm's most recent piece) the relevance of writing center work to the field as a whole, as though it were not an area as self-evident as, say, basic writing or computer technology.

Early articles on staff training turn away from a consideration of the writing lab as writing lab and turn toward a consideration of the writing lab as a site for work more generally recognizable as contemporary composition studies. In a 1982 CCC article, James Collins carefully lays out the rationale for a teacher training program set up to run through his writing lab. North's article in that same issue returns us to a more familiar writing center discussion-tutor training-but his essay too, in contrast to earlier pieces, integrates work emerging on the composing process with the work of tutors in the writing center, positioning the tutor securely within the process of writing. While this may be merely a slight shift from earlier work, all of which foregrounds the writing lab and backgrounds the writing, it is a significant one and one which sets the stage for North's next piece, the one which has received, in the writing center community at least, the most attention: his 1984 polemic "The Idea of a Writing Center."

Between North's 1982 and 1984 pieces, the only article on writing centers appearing either in the pages of CCC or College English is Harvey Kail's "Collaborative Learning in Context: The Problem with Peer Tutoring." Kail's article, though it is rarely mentioned, actually prefigures North's "Idea" in both tone and perspective. And, more than either of North's pieces, it suggests the radical/dialogic/liberatory shift which marks much recent writing center work. Kail makes clear that the "problem" of peer tutoring is likely to be the faculty, who are uncomfortable with the shift from a lineal to a non-lineal pedagogy presupposed by a peer tutoring program and who are anxious about the potential such a program has for exposing them and their methods. Kail, therefore, resists the construction of writing center as "other" by downplaying the significance of the site and foregrounding the significance of the method, one which Kail suggests could be equally applicable (if difficult to implement) in classrooms as well as in the writing center. By the end of the article, Kail does not seem at all certain about the continuation of peer tutoring and suggests instead that peer tutoring pro- 
grams may simply require a greater epistemological shift than our academic institutions can bear (598). Like North, Kail insists that peer tutoring be done "right," in a manner which by design complicates the teacherstudent-tutor-director relationship in ways that the lineal model of fix-it shop tutoring did not.

North's "Idea" continues to problematize that relationship; and, as such, it represents the preeminent admission of the at-odds-ness noted throughout this essay. The piece is replete with examples of the ways in which goals of the writing center staff often conflict with institutional goals as those goals are represented by faculty, by administrators, even by the students themselves. North's model is reminiscent of the Rogerian writing center, the sanctified, professional space in which one can engage in counter-hegemonic operations to ultimately sustain institutional goals, often at the expense of the students it purports to serve. That agenda, though, is couched in a decidedly Woolfian interpretation of the value of the writing center, one emphasizing the necessity of room and time and teachable moments.

There is, of course, value in making a case for such luxuries, perks which are too few and far between, particularly for writing center professionals, many of whom still have no job security, heavy teaching loads, and little if any institutional support. "Idea" has been canonized, then, less for what it says about the method of the writing center, philosophies even North himself has admitted are problematic ("Revisiting"), than for what it suggests about the professionalization of the practitioner. "Idea" carved out an institutional space where it was necessary, even preferable, to just do, where doing was in fact the height of professionalism, an appealing prospect, in light of composition's recent turn to the theoretical, for those who won't or simply can't sit back and ponder the cause before (or even after) dealing with the effect. But where does this leave us as a scholarly community?

At the 1997 meeting of the National Writing Centers Association, Christina Murphy, one of the association's recent past-presidents, referred to what she perceived as a "bankruptcy of writing center scholarship." Though her comment predictably troubled much of the membership, it did not then and it does not now strike me as wrong. I will admit it, even though I am afraid to: much recent work in writing centers is not interesting to me. While such an admission may sound petulant, it is nevertheless an important criteria for intellectual activity. I say this especially because I am committed to a career in the writing center, because I desperately need to find the space for the kind of sustained intellectual inquiry which led me to choose academia as a profession, and because I know the writing center potentially could be that space. So, while the issues most recent writing center discussions focus on-how to fund, set-up, and publicize an on-line 
writing lab, for example-are all issues that I too must consider in the administrative execution of my job, they do not get at what is most challenging to me about my work in the writing center: the excessive institutional possibilities that the writing center represents. The way in which the writing center exceeds its space, despite the university's best efforts to contain it; the way in which the writing center exceeds its method, with tutors going off-task, with students (more often than not) setting them back ontrack, negotiating academic demands in the midst of an e-mail message from a distant love, a bagel and a smear from the downstairs coffee bar, a brief but meaningful announcement from a comrade in flip-flops and shades that the sun is finally shining and everyone should march outside.

These are moments not accounted for, really, in North's version of the writing center, and the question is, I suppose, why not? It is possible that they didn't even occur, though it seems more likely that they did and that they were just not considered important. They may have even been viewed as drawbacks in a writing center desperately seeking to be taken seriously, to attain some measure of disciplinary status. Patricia Harkin has written that "disciplinary inquiries can be strategies of containment; these strategies achieve coherence by shutting out or repressing the contradictions that have their source in history" (135). Though North's essay does more to expose contradictions than it does to suppress them, it ultimately attempts to contain the interpretation of the writing center, both in terms of site and method. As such it constructs the writing center as a predictably disciplinary entity, complete with spatial boundaries, established protocols and procedures, and reasonably replicable methods.

Yet the writing center is most interesting to me for its post-disciplinary possibilities, for the contradictions it embraces, for its tendency to go offtask. And I would like to argue, as I come to the conclusion of this history, that we would do well to think of the future of writing centers in excessive terms. To do so does not mean that writing centers should grow as large as they possibly can or spend as much money as they can get their hands on or stake out claims all over campus in order to ensure their survival. Rather, an excessive theory of writing center operations requires us to seek out the overflow of the expected in all its forms, asks us to create a space for play, as Nancy Welch suggested in a recent keynote address. An excessive writing center rejects the "form-as-reproducible" model (Sirc 10) of low-risk/lowyield tutoring in favor of higher-risk/higher-yield strategies. It does away with the script for the how-to-write-a-research-paper session or the whythe-writing-center-does-not-constitute-plagiarism defense and insists on less predictable but potentially more productive conversations which wander, circle, and return again to the point where they began. This is not a failing; it is instead a part of the process, the nature of scholarly inquiry, and it 
is what we must engage in ourselves if we hope to model it for our students. Because, for all of our championing of process and collaboration, we have actually constructed writing centers that are all about the singular object, the "thing" that we can point to, and neither the number of computers we install nor the number of students we tutor in a year-evidence, surely, of our fetishization of the finished product-will fundamentally alter that fact. We must, instead, pay more attention to the things that don't always demand our attention, must remember that we only get answers to the questions that we ask and that the asking determines the answers.

Authoring this history has been, for me, a process of de-familiarizing the familiar in order to open up space for new possibilities. Foucault writes that the practice of genealogy invites us "to study the beginning-numberless beginnings whose faint traces and hints of color are readily seen by an historical eye" ("Nietzsche" 145). The history of the writing center is, as I suggested earlier, best told as a history whose intentions are cross-cut by Foucauldian accidents, by unanticipated outcomes. Administrators certainly didn't envision it as a source of radical or liberatory pedagogy, though it is often that. Bruffee didn't initially imagine it as a place where students and tutors alike would profit intellectually, though it is clearly that. Many of us find it difficult to believe that the writing center may be a site of regulation rather than liberation, though it seems certainly that (Grimm, "Rearticulating"). We are left to wonder, then, what we are failing to imagine now for our writing centers. What "faint traces and hints of color" are not present to our eyes? What is being left out of our discussions on teaching writing by our failure to account for the work of the writing center in a critically intellectual manner? And, conversely, what is being left out of our discussions on writing centers by our inability to account, in complex ways, for its relationship to the teaching of writing? By our continued insistence that writing centers give us simply the hard numbers, just the facts?

The Foucauldian accident is, of course, all about perspective, about who gets to author the history being told. Other stories can be brought to light, stories which write the developments of the contemporary writing center in theoretically sophisticated ways, stories which consider the critical capacities of networking, of linking writing centers with WAC programs, of placing peer tutors in classrooms. Stories which draw on the history, and the continued problematic, of the at-odds-ness inherent in the writing center in order to pry apart distinctions which have become fused in our discussions of writing center theory and practice, enabling us to tease them out in a manner consonant with our intimate relationship to the teaching of writing in our institutions. All of these stories can be written. Should be written. Are waiting to be written. Will be written.

Or not. 
Acknowledgments: The following people have offered careful readings as well as much-needed support and encouragement throughout the development of this project: Steve North, Nancy Welch, Neal Lerner, Meg Carroll, Peter Gray, Mark Hurlbert and, especially, Geoff Sanborn.

\section{Notes}

1. Horner's article summarizes the findings of his master's thesis, an empirical study which sought to compare the effectiveness of the laboratory method to the effectiveness of the lecture method. In the end, the results, which are fairly inconclusive, are far less interesting than his point-by-point explanation of the laboratory method.

2. See, for example, Grandy, who describes a writing laboratory in which lecture and lab are combined in one course. On days when the class meets in the lab, students must have some writing completed upon their arrival (thus distinguishing it from Horner's model). Once in the lab, students take their places in assigned seats and begin to write, while "those in charge go around as rapidly as possible to see that no one is off on the wrong track" (374). Grandy acknowledges, "This sometimes happens, and that student has to be put right at once" (374).

3 . It is worth noting that the laboratory described by Grandy was administered through the College of Science, Literature, and the Arts solely for students enrolled in Freshman English at the University of Minnesota. This differentiates it from the writing laboratory that was operating at the same time through the General College there. Grandy notes, "[T]he work as carried on in [the General] College is very different" (i.e. remedial) (372).

4. Following the publication of the Commission's report, increasing numbers of schools tied their communications programs to a common core of knowledge emphasizing democratic ideals, in part, it seems likely, to secure a portion of the committee's federal

\section{Works Cited}

$\rightarrow$ Almasy, Rudolph. "Instructional Materials for the Writing Laboratory." CCC 27 (1976): 400-03.

$\rightarrow$ Bailey, J. O. "Remedial Composition for Advanced Students." College English 8 (1946): $145-48$.

Berlin, James A. Rhetoric and Reality: Writing Instruction in American Colleges, 1900-1985. Carbondale: Southern Illinois UP, 1987. funding recommendations (Berlin, Rhetoric and Reality 99).

5. For example, Bailey notes that since students tried to avoid being sent to the lab, they became especially careful about neatness and surface concerns (148).

6. Kitzhaber traces Project English, a program underwritten by the government to update the English education curriculum in America. "Project English," Kitzhaber writes, "was, in the first place, little more than a somewhat delayed reflex action to the stimulus provided by Russian scientific achievements" (135). The primary outcome of Project English, interestingly enough for the purposes of this article, was the development of Curriculum Study Centers, which were touted as "the chief source of hopes for a 'New English' worthy to stand alongside the 'New Math' and 'New Science'" (135).

7. Here, the influence of the Commission's 1947 report, Higher Education for American Democracy, seems undeniable. The report offered clear support in its plan for increasing the profile of the community college system; and though the committee cautions against the development of purely vocationallyoriented technical colleges, it appears the warnings went unheeded (69-70).

8. See, for example, the histories of writing centers recounted in Kinkead and Harris' Writing Centers in Context: Twelve Case Studies.

9. The Writing Lab Newsletter, founded by Muriel Harris, went to press in 1978 and The Writing Center Journal, with co-editors Stephen North and Lil Brannon, in 1980. 
. "Peer Tutoring and the 'Conversation of Mankind'." Writing Centers: Theory and Administration. Ed. Gary Olson. Urbana: NCTE, 1984. 3-15.

Carino, Peter. "Early Writing Centers: Toward a History." Writing Center Journal 15 (1995): 103-15.

$\rightarrow$ Collins, James L. "Training Teachers of Basic Writing in the Writing Laboratory." CCC 33 (1982): 426-33.

Cooper, Marilyn M. “'Really Useful Knowledge': A Cultural Studies Agenda for Writing Centers." Writing Center Journal 14 (1994): 97-111.

$\rightarrow$ Davidson, Levette J. and Frederick Sorenson. "The Basic Communication Course." College English 8 (1946): 83-86.

Foucault, Michel. Discipline and Punish:Trans. Alan Sheridan. 2nd ed. New York: Vintage, 1995.

—. "Nietzsche, Genealogy, History." Language, Counter-memory, Practice: Selected Essays and Interviews by Michel Foucault. Ed. Donald F. Bouchard. Ithaca: Cornell UP, 1977. 139-64.

$\rightarrow$ Gere, Anne Ruggles. "The Extracurriculum of Composition." CCC 45 (1994): 75-92.

$\rightarrow$ Grandy, Adam G. "A Writing Laboratory." English Journal 25 (1936): 372-76.

$\rightarrow$ Grimm, Nancy. "Rearticulating the Work of the Writing Center." CCC 47 (1996): 523-548.

- "The Regulatory Role of the Writing Center: Coming to Terms with a Loss of Innocence." Writing Center Journal 17 (1996): 5-29.

$\rightarrow$ Guyer, Byron. "Some Uses of Linguistics and Semantics in Freshman English." College English 19 (1958): 309-12.

Harkin, Patricia. "The Postdisciplinary Politics of Lore." Contending with Words: Composition and Rhetoric in a Postmodern Age. Eds. Patricia Harkin and John Schilb. New York: MLA, 1991. 124-38.

Higher Education for American Democracy, A Report. Vol. 1. Washington: US Government Printing Office, 1945.

$\rightarrow$ Horner, Warren B. "The Economy of the Laboratory Method." English Journal 18 (1929): 214-21.

$\rightarrow$ Kail, Harvey. "Collaborative Learning in Context: The Problem with Peer Tutoring." College English 45 (1983): 594-99.

Kail, Harvey and John Trimbur. "The Politics of Peer Tutoring." WPA: Writing Program Administration 11.1-2 (1987): 5-12.
Kelly, Lou. "One on One, Iowa City Style: Fifty Years of Individualized Instruction in Writing." Writing Center Journal 1 (1980): 4-21.

Kinkead, Joyce A. and Jeanette G. Harris, eds. Writing Centers in Context: Twelve Case Studies. Urbana: NCTE, 1993.

Kirkpatrick, Carolyn. "The Case for Autotutorial Materials." New Directions for College Learning Assistance: Improving Writing Skills. Eds. Thom Hawkins and Phyllis Brooks. San Francisco: Jossey-Bass, 1981. 15-23.

$\rightarrow$ Kitzhaber, Albert. "The Government and English Teaching: A Retrospective View." CCC 18 (1967): 135-41.

Lerner, Neal. “Drill Pads, Teaching Machines, and Programmed Texts: Origins of Institutional Technology in Writing Centers." Wiring the Writing Center. Ed. Eric H. Hobson. Logan: Utah State UP, 1998. 119-36.

- "The Writing Conference as Dominant Practice: An Historical View." 12th Annual New England Writing Centers Association Conference. Amherst, MA. 2 March 1996.

Lomuscio, James. "Students Get Help at Writing Center." Fairfield Fairpress 3 March 1982: A6.

$\rightarrow$ Millet, Stanton and James L. Morton. "Round Table: The Writing Laboratory at Indiana University." College English 18 (1956): 38-39.

$\rightarrow$ Moore, Robert H. "The Writing Clinic and the Writing Laboratory." College English 11 (1950): 388-393.

$\rightarrow$ North, Stephen M. "The Idea of a Writing Center." College English 46 (1984): 433-446. 1998. 2. Personal Correspondence. 7 January - "Revisiting 'The Idea of a Writing Center'." The Writing Center Journal 15 (1994): 7-19.

$\rightarrow$ - "Training Tutors to Talk about Writing." CCC 33 (1982): 434-441.

Nystrand, Martin, Stuart Greene, and Jeffrey Wiemelt. "Where Did Composition Studies Come From? An Intellectual History." Written Communication 10 (1993): 267-333.

$\rightarrow$ Perrin, Porter G. "Maximum Essentials in Composition." College English 8 (1947): 352-360.

Sirc, Geoffrey. "Writing Classroom as A \& P Parking Lot." Pre/Text 14.1-2 (1993): 27-70. Rpt. at http://jefferson.village.Virginia.EDU: 80/ spoons/pretext/sircl.html. 2-34. 
Shor, Ira. Culture Wars: School and Society in the Conservative Restoration, 1969-1984. Boston: Routledge, 1986.

Sorenson, Frederick. "The Basic Communications Course Reconsidered." College English 10 (1949): 324-28.

$\rightarrow$ Stanley, Carrie Ellen. "This Game of Writing: A Study in Remedial English." College English 4 (1943): 423-28.

Trimbur, John. "Peer Tutoring: A Contradiction in Terms?" Writing Center Journal 7 (1987): 21-28.
Veit, Richard C. "Are Machines the Answer?" Writing Lab Newsletter 4.4 (1979): 1-2.

Warnock, Tilly and John Warnock. "Liberatory Writing Centers: Restoring Authority to Writers." Writing Centers: Theory and Administration. Ed. Gary Olson. Urbana: NCTE, 1984. 16-23.

Welch, Nancy. "Playing With Reality: Writing Centers After the Mirror Stage." 14th Annual Northeast Writing Centers Association Conference. New London, CT, March 1998. 